\title{
Attracting and retaining school leaders: A case study of two municipalities in Sweden.
}

Cresantus Biamba ${ }^{1}$ and Signhild Olsson ${ }^{2}$

1 Department of Educational Sciences, University of Gavle, Sweden; Email: Cresantus.biamba@hig.se

2 Department of Educational Sciences, University of Gavle, Sweden, Email: signhild.olsson@hig.se

* Correspondence: Cresantus Biamba, Email: Cresantus.biamba@hig.se

\begin{abstract}
This article reports on the findings of a research project examining how to create a profession that is attractive and fulfilling for new and existing school leaders in two different municipalities in Sweden. The project set out to explore how work environments, career structures, salaries, and working conditions can contribute to attracting, retaining, and motivating school leaders to stay longer in the profession. To realise this objective, the study adopted a qualitative research design. Data was collected by carrying out semi-structured interviews with a sample of five school leaders in two different municipalities to investigate their experiences and views of the profession. The findings demonstrate that school leaders' working conditions play a more critical role in their decisions to stay or leave the profession than financial compensation. The study also shows an unequal allocation of resources, both in terms of support functions and the limited time available for in-service education.
\end{abstract}

Keywords: Municipality, profession, school leaders, and working conditions 


\section{Introduction}

Recruiting and retaining school leaders has long been a major problem in most forms of schooling in Sweden and internationally. This problem often has a devastating effect on a school's continuity and long-term perspective on quality work. In Sweden, this has led to an ongoing national debate about how to reduce the turnover of school leaders (DarlingHammond, 2010, Lärarförbundet, 2016, Skolledarförbundet, 2020). When a school's long-term development work is fragmented, the consequences are a lack of goal fulfilment, a short-term perspective on quality, and teachers who do not develop in their work (Jarl et al., 2018).

Nowadays, schools and school leaders are experiencing a growing pressure to deliver highquality education. In addition, the consensus is that school leaders should be encouraged and supported in the school context to develop professionally to deliver the required quality (Little 2002). The educational values of school leaders, together with their reflective strategies and leadership practices, shape the internal processes of school organisation and determine which pedagogies are adopted, all of which have a significant impact on student learning (Day et al., 2010). A substantial body of research also suggests that school leaders make a difference and influence student achievement (Biamba, 2012, Frelin and Fransson, 2019, Leithwood and Levin, 2005).

Attracting, selecting, and retaining effective school leaders is critical for the success of education systems. Given the diverse challenges regarding the quality and quantity of the teacher and school leader workforce, a key question for policymakers is how to create a profession that is attractive and fulfilling for new and existing teachers and school leaders.

This study aim therefore to examine how work environments, career structures, salaries, and working conditions can contribute to attracting, retaining, and motivating school leaders to stay longer in the profession. The study's research question is:

- How can the work of school leaders be made more attractive so that they are motivated to stay in the profession?

\section{The evolving roles of principals from a Swedish historical perspective.}

Historically, effective school leaders have only needed to have sound managerial and political skills. However, in the 21 st century, school leaders are now expected to have different kinds of leadership skills. This stems from the fact that in addition to instructional and programming 
pressures, today's school leaders also face challenges such as budgetary reductions, school safety, administrative duties, supervision, data management, and marketing. Thus, in addition to effective instructional leadership skills, a school leader's effectiveness in this new educational era will also require complex knowledge and skills related to organisational culture and management. According to Elmore (as cited in Lashway, 2002), "this requires not just innovative practices, but a different mindset" (p. 3).

The past 30 years have seen a proliferation of numerous education reforms aimed at raising pupils' achievement standards. Due to the complexity and constantly evolving school settings that these reforms have created, school leadership now has a greater focus in international education and is increasingly recognised as playing a key role in improving student outcomes (Day, Gu \& Sammons, 2016).

The governance of the Swedish school system has changed from a governance based on rules and regulations to one based on goals and performance. The power centre for goal-based governance is found in the steering documents that set the goals for school activities. How the goals are processed and operationalised internally in schools is determined by Sweden's 290 municipalities and is manifested in the school leaders' work (Ekholm et al. 2000).

In 2011, the Swedish Education Act (2010: 800) changed the role of the school leader in one of the greatest school reforms of modern times. The Act states that a school leader who leads and coordinates the work at a preschool or school unit must be in place (Chapter 2: 9). The Act also states that the school leader should be called a principal who is empowered to delegate assignments to an employee who has sufficient competence and experience to perform some of the managerial tasks. The principal is the person who decides on their internal organisation and distributes resources according to the children's and pupils' needs (Chapter 2:10). The Act also emphasises that each principal must undergo an in-service education that is focused on the school's assignments (Chapter 2:12).

In Sweden, there has been a change in pedagogical leadership due to the introduction of free school choice and New Public Management thinking. School leaders have progressed from being pedagogical leaders to pedagogically successful leaders, where the focus is on creating a successful school that attracts more pupils (Giota, 2013). Nehez (2015) writes in her action research that a school is classified as successful when it has high results and goal fulfilment. This means that school leaders' leadership is of great importance for both the pupils' and the school's development. The school has today been forced into the private business world and 
striving for efficiency that is measured by goal and result management. Giota (2013) claims that a focus on goal fulfilment makes it more difficult to achieve inclusion and a good learning environment that is adapted to the pupils' needs. The time that teachers have at their disposal is not enough to create the relationships that are needed to develop a multifaceted learning environment for all pupils.

Erlandsson (2015) highlights the importance of unpretentious leadership, where all employees are involved in the work of developing and taking responsibility for the school's learning environment. Ludvigsson (2009) states that the relational perspective between various employees is what should be in focus, as well as the relationships between school leaders, tea $\chi$ hers, and pupils. The researcher highlights the importance of understanding between individuals and the organisation. This is best created in everyday informal meetings that allow relationships and cultures to be created through participation (Ludvigsson, 2009). Lindqvist \& Nilholm (2013) emphasise the importance of creating conditions for communication that lead to good relationships, consensus, and collegial learning.

Nehez (2015) writes that leadership in school depends on the school's context and that school development initiatives are affected by how the school is organised and the kind of culture that prevails in it. The study also shows that rapid changes have occurred in the school system over the past two decades. Most often, it is the planned school changes that are given the most space and time because they are based on the achievement of goals and objectives. However, Nehez's (2015) study shows that rapid change is more difficult to maintain over time, as it is affected by resources, economy, social, and political factors. Something that Ståhlkrantz (2019) highlights in her critical policy analysis is that school leaders' leadership is constantly influenced by political decisions and guidelines, which complicates the design of a sustainable organisation with development opportunities in the school's culture. Erlandsson (2015) emphasises the importance of collaboration and dialogue between the various levels in the chain of command, i.e., at the political, school leadership, and teacher-to-pupil levels, to create an accessible learning environment. Furthermore, Ståhlkrantz (2019) writes that there are no simple organisational solutions that lead to better results and successful schools. Each school is unique and requires an adapted leadership that is based on the prevailing school context something that conflicts with the political guidelines and conditions that school leaders are obliged to follow and accept. Ludvigsson (2009) emphasises in her case study that simply relying solely on the school leader's leadership for the development of the school culture and learning environment is short-sighted. The study further shows that leadership needs to be 
distributed between different employees with the task of leading the school towards the set goals, which is referred to as distributive leadership. In distributive leadership, communications between the school leader and employees form the basis of a functioning and participatory organisation that is sustainable over time.

As previously mentioned, school reforms have led to a decentralisation and marketing of schools, which has in turn led to increased control, reduced equivalence, poorer pupil results, and reduced public confidence in the education system (Evers, Kneyber \& Kornhall, 2017). According to Berg (2020), this has led to a three-part control system in the school that is characterised by a) market adaptation and pupils being able to choose which school to attend, b) a decentralisation of the distribution of resources to schools and municipality-controlled school finances that affect class sizes, teachers' services, teaching materials and skills development and c) teachers being employed by the municipality and a centralisation that entails state control of the school through legislation, targeted and general state grants, steering documents and statutory compulsory schooling.

\section{Long-term school leadership in Sweden compared to other European countries}

According to a report published by the Organisation for Economic Co-operation and Development (OECD) in 2014, attracting talented individuals to a career in school is a pressing concern in many OECD countries, particularly those with rising pupil enrolments or a large proportion of teachers, school leaders or other staff approaching retirement age. Retaining the best teachers and leaders, motivating them throughout their careers and enabling them to use their talents effectively to foster pupils' learning and well-being lie at the heart of what makes a successful education system.

The OECD Teaching and Learning International Survey (TALIS) points to significant differences in the social and professional status of school leaders and public perceptions of career in schools in OECD review countries (OECD, 2018; OECD, 2014). The status of teachers and school leaders is driven by the material and intellectual fulfilment that work in schools provides and often mirrors the extent to which teachers and leaders are capable, enabled, and trusted to use their professional expertise. The TALIS survey also shows that the turnover of school leaders is higher in Sweden than in other comparable countries. According to TALIS, although Swedish school leaders tend to stay at their school for an average of two to three years, their counterparts in the other Nordic and OECD countries stay for five years. 
Drysdale et al. (2016) claim that the nature of school leaders' work is changing and that this leads to complications. Pollock et al. (2015) provide evidence of the full extent of the nature of school leaders' work and focus on particular aspects of the role, such as leadership (Gurr 2015; Leithwood, Patten \& Jantzi 2010), trust (Tschannen-Mora \& Gareis 2015) and the interactive nature of administrative work (Spillane 2015). In this way, they provide a more accurate picture of school leaders' work.

The Swedish Schools Inspectorate (2019) highlights the important role of school leaders in leading and developing the teaching staff's work for high-quality education. Frequent changes in school leaders often result in a poorer quality education, which makes it more difficult for pupils to achieve set goals. Other consequences of frequent changes in school leadership include unstable management functions that require constant reorganisations, which in turn affect teachers' long-term perspectives of their work (Håkansson and Sundberg, 2016).

As stated above, it is therefore important for decision-makers to be able to recruit, make good selections, and retain professional school leaders and in that way offer high quality education. Here, both the internal and external motivations of the school leader are closely intertwined and decision makers need to take both aspects into account if they want to increase the attractiveness of the profession and motivate school leaders to stay put.

\section{The school leader's assignment as a pedagogical leader from a governance perspective}

The development of the roles and responsibilities of school leaders is intertwined with and impacted by a series of educational reforms and mandates. Reviewing the literature provides a more informed understanding of how changes in external circumstances have affected the practices of school leaders over time.

In Sweden, Ivarson Alm (2014) has shown how school leadership and leadership role have undergone major changes. Instead of schools having head teachers who are responsible for a few departments, they now have school directors who are responsible for a number of departments in the same area. It is therefore important that school leaders know what their current role is. Ivarson further explains that today's school leaders are responsible for arranging substitutes, planning, ordering food, conducting parent talks, and documenting, which has led to the need to develop their management and control skills. According to the author, these possibilities are stated in the new steering documents, such as the Education Act and the National Curriculum. 
Katarina Ståhlkrantz (2019) carried out a study on educational leadership in which she examined educational policy texts from the 1950s to the 2010s. The study shows that the pedagogical leader has been constructed on the basis of the historical and social educational policy context that has been distinguished over time. She also emphasises that the pedagogical leadership of school leaders is regarded by politicians and school authorities as a problem and even by the school leaders themselves. The general perception is that not enough time is allocated to the pedagogical assignment and that administrative and organisational tasks are a major part of a school leader's work. In her study, she discerned six turning points for how pedagogical leadership has been constructed.

The emergence of the rational pedagogical leader was the first turning point to be mentioned in the 1961 school administrative investigation (SOU, 1964: 53). Here, the leader was defined as qualified and rational with a high status and who exercises their pedagogic leadership as effectively as possible to achieve the highest possible productivity. Here it was expected that by being rational, the school leader could create space for pedagogical leadership.

In connection with the SIA investigation (SOU, 1974: 53), the professional educational leader can be identified as the second turning point. Here, all tasks were regarded as pedagogical and school leaders were asked not to differentiate between administrative and pedagogical tasks. The perception was that a good pedagogical assessment was required to be able to carry out the simplest of the administrative tasks in the school in which they were to be implemented.

A greater emphasis was placed on the legal responsibility of school leaders and in the Steering Committee's report (SOU 1988: 20) it was this that led to the next breakpoint - the creation of a legally responsible educational leader. This turning point highlights financial tasks as a clear part of the school leader's pedagogical leadership. The curriculum also emphasises the school leader's legal liability.

A new turning point was identified in the 1990s when the 1995 School Committee (SOU1997: 121) proposed that school governance should be decentralised. The effective and professional pedagogical leader was now someone who would effectively and professionally lead their school with the best results. The successful pedagogical leader can be discerned in the goaloriented school of the 21 st century, where even higher expectations are placed on pedagogical leadership. A report on the school's management structure (SOU, 2004: 116) led to the fifth 
breaking point, which was that the educational leader was expected to successfully navigate their own school to the best results.

The sixth and final discursive turning point in Ståhlrantz's study occurs in connection with the leadership education programme for school leaders that was launched in 2011. Now, an effective, successful, and instructive educational leader is expected to have a good knowledge of the factors that lead to successful teaching and high results. School leaders are thus expected to be instructive pedagogical leaders who make classroom visits and are able to give teachers feedback, guidance, and constructive criticism.

In several reports (Skolverket, 2005, 2007, 2011d), the Swedish National Agency for Education has highlighted the complexity of pedagogical leadership and stated that this kind of leadership is a prerequisite for the school's pedagogical quality. In the Agency's general advice on systemic quality work (2012), it states that resources must be organised at the school in such a way that the school leader can also function as a pedagogical leader.

There are several definitions of pedagogical leadership, what it means and how it should be exercised. The Swedish Schools Inspectorate (2012: 1, p. 6) defines it as follows:

Pedagogical leadership is all about interpreting the goals and describing activities for a good goal fulfilment in relation to the national goals of the school and to improve the school's results so that each student reaches as far as possible in their learning and development. This means that the principal must have knowledge of and competence to interpret the assignment, translate it into teaching, lead and control learning processes, and create understanding among employees for the connection between effort and results.

In several reports $(2012 ; 2010,2014)$, the Swedish Schools Inspectorate draws attention to the fact that in Sweden school leaders lack pedagogical leadership, mainly because this is not given the necessary priority due to administrative tasks occupying the majority of their time. This is interpreted as the authorities perceiving a certain competition between a pedagogical and administrative leadership. The Swedish Schools Inspectorate's report from 2014 emphasises the school leader's responsibility to create activities that enhance pupils' learning and the quality of the school's teaching. 
In a research compilation published on the Swedish National Agency for Education's website, Skott \& Nordzell (2020) highlight that school professionals also have thoughts and perceptions about pedagogical leadership (Johansson 2016). Johansson thinks that Swedish schools would benefit from a more stable and clearer meaning of the term, whereas other researchers emphasise the importance of capturing the complexity that the school leader needs to handle (Berg, 2015; Blossing, 2011).

When the Swedish Schools Inspectorate examines school leaders' internal work, the leaders can be affected by the Inspectorate's definition of how pedagogical leadership should be carried out. This subject is well debated among Sweden's school leaders, as it is often felt that the conditions for conducting the expected pedagogical leadership in the school are lacking (Nilsson, 2020)

It is widely accepted that school leaders are vitally important. However, ever-rising accountability standards, limited authority over key decisions, and mediocre salaries make the job more demanding and less attractive to talented leaders. At a time when schools need highquality leaders more than ever, the gruelling nature of the job makes it a tough sell. School leaders also tend to come and go. Recruiting and retaining teachers is therefore a constant concern for school leaders at all levels in Sweden. This concern has also turned into an ongoing national debate in Sweden about how to address teacher and school leader shortages (Lärarförbundet, 2016).

Matz Nilsson (2020) maintains that the turnover of school leaders in Sweden is devastating and has accelerated alarmingly in recent years. He goes on to say that, it is imperative to start talking about why the stability of leadership in preschools and schools has been lost. He further attributes this to three important areas from a leadership perspective:

A governance model within the school that no longer works, the tug-of-war between the state and the principals is increasing and a salary development for the country's school leaders that no longer takes into account the scope and responsibilities of the assignment. To that end, the work environment is becoming increasingly strained.

Weyler (2020) mentions in an article that statistics from the Swedish National Agency for Education show that the turnover rate of primary and secondary school leaders is very high and that a majority of leaders change jobs over a five-year period. The academic year of 2014/15 has been compared with that of 2018/19, where 80 per cent of school leaders changed jobs after 
five years, which Weyler regards as alarming. In 2018/19, only two out of ten school leaders remained at the same school as in 2014/15.

Gunnar Berg expressed himself as follows in an article in the publication, School and Society in 2018 about school leaders' experiences of what he calls cross-pressure and the nature of their tasks:

As I see it, one of the main tasks of the ongoing state Rector's program is to provide school leaders with insights that lead to the cross - pressure's tense demands and expectations becoming visible and thus professionally manageable. Having full control over the diverse ingredients of cross-pressure is thus not only a prerequisite for workpromoting school development, but also opens up for an increased degree of professional security for school leaders.

Based on the Swedish Schools Inspectorate's definition of pedagogical leadership, the school leader's assignment covers everything that happens in the school's everyday work, which can be described as operationally responsible leadership.

The concept of cross-pressure reappears in school research (Berg, 2018) as a perspective on the complexity of school leaders' responsibilities and the constant tension between a school's stakeholders, state and municipal governance and the expectations of civil society actors, especially guardians. School leaders are also responsible for the schools' results, which includes personnel management, work environment processes, budget and financial processes, premises, managing IT systems, reporting, and follow-up.

\section{The present study and its setting}

We chose two municipalities in different parts of Gavleborg County which in recent years have tried to improve their employment processes. To conduct the study, we teamed up with RucX, the Regional Centre for School Development, with which we have successfully collaborated for some time. RucX's expertise lies in educational leadership and helps schools in the county to expand their teacher and principal networks. We interviewed five school leaders in two different municipalities during the spring and summer of 2020 and reviewed the research material and the relevant literature. 


\section{Methods and materials}

According to Ahrne \& Svensson (2015), a qualitative method is based on interviews, observations, or text analyses. When choosing a qualitative method, the researcher should be aware that their own previous experiences and perspectives can affect the results, especially when interpreting the interview responses. The purpose of this study was to investigate how school leaders' work environments, career structures, salaries, and working conditions can contribute to attracting, retaining, and motivating them to stay longer in the profession. A qualitative method using interviews was regarded by the researchers as the most appropriate way of collecting the views of the chosen school leaders. Ahrne \& Svensson (2015) state that interviews can be designed in different ways, for example, with open-ended questions, semi structured interviews with follow-up questions, or in-depth interviews with a view to acquiring a deeper knowledge of the different interviewees' perspectives.

The study therefore used a qualitative method which, according to Bryman (2011), helped to understand the participants' thoughts and opinions. Tivenius (2015) states that a qualitative method provides an understanding of how the subject is seen from different perspectives.

\section{Analysis}

Based on the study's purpose of investigating how to make school leaders' work attractive and motivate them to stay in the profession, interviews were conducted with five school leaders from the two chosen municipalities. Each interview lasted for one hour and was recorded to facilitate transcription. According to Bryman, the recording of interviews facilitates the analysis of the material. The recorded interviews were then transcribed verbatim, and the transcripts were read several times to get a sense of the meaning of the data corpus. During this process, codes were inductively developed from the data and identified a priori based on the school leaders' responses. The school leaders' responses were then analysed to identify the similarities and differences in their approaches. In this context, a 'mind map' was used to categorise and analyse the findings, as suggested by Bryman (2011). The school leaders were assigned the designations L 1, L 2, L 3, and so on, partly to make visible what each school leader said and partly to protect their identities. 
Table 1. Background information of the respondents

\begin{tabular}{|l|c|c|c|c|c|}
\hline $\begin{array}{l}\text { Background } \\
\text { information }\end{array}$ & L1 & L2 & L3 & L4 & L5 \\
\hline Sex & Female & Female & Male & Female & Female \\
\hline $\begin{array}{l}\text { Experience as } \\
\text { a school leader }\end{array}$ & 8 yrs & 6 yrs & 3 yrs & 2 yrs & 3 yrs \\
\hline $\begin{array}{l}\text { Educational } \\
\text { background } \\
\text { school } \\
\text { teacher }\end{array}$ & Primary & Pedagogy & $\begin{array}{l}\text { Teaches years 1- } \\
7 \text { in } \\
\text { mathematics, } \\
\text { nature-oriented } \\
\text { subjects, sport }\end{array}$ & $\begin{array}{l}\text { teaches years1-7 } \\
\text { in Swedish, } \\
\text { society-oriented } \\
\text { subjects, } \\
\text { Swedish as a } \\
\text { second language }\end{array}$ & $\begin{array}{l}\text { Teaches } \\
\text { years 1-7 in } \\
\text { Swedish, } \\
\text { society- } \\
\text { oriented } \\
\text { subjects, } \\
\text { English }\end{array}$ \\
\hline $\begin{array}{l}\text { Completed } \\
\text { school leader } \\
\text { education }\end{array}$ & 2012 & 2014 & Ongoing & Ongoing & Ongoing \\
\hline
\end{tabular}

\section{Ethical issues}

In the study, we followed the basic ethical principles relating to the information requirement, consent requirement, confidentiality require $\mu$ ent, and utilisation requirement to protect the identities of the respondents and municipalities (Swedish Research Council, 2017). A letter was first of all sent to the school leaders who had volunteered to take part in the study to introduce ourselves, provide information about the purpose of the study, and request their participation in the interview. After obtaining their consent, we booked day and time for the interviews. The respondents were informed that their participation in the interviews was voluntary and that they were free to leave the study at any time. The respondents were also informed that their identities and those of the schools would be protected and that all gathered material would be treated confidentially. 


\section{Results}

The results discussed in this section refer to the first phase of the study. In this phase, five school leaders from primary and secondary schools were interviewed in a semi structured way. The interviews explored the school leaders' perceptions of their own professional development and their professional interactions with other team members. Some of the school leaders who took part in the study had already completed the leadership programme, while others were studying the programme in parallel with their professional duties. The results of the study are presented under the following six themes: cooperation, management, support/support in general, pedagogical leadership, working conditions, responsibilities/tasks, and complexity of tasks.

\section{Cooperation}

The respondents highlighted collaboration with colleagues as energising and the importance of having a good collaboration with the municipality's education department. Collaboration with other departments in the municipality to which the school leaders were required to provide information that was not within the framework of their work took time and energy. Some of the respondents saw collaboration as a prerequisite for being able to work effectively. This is how two of the respondents responded to this theme:

[...] and I am more interested in working with people than in myself and I usually think of us as a team. (L2)

What gives energy is when you have motivated the staff around you, and pupils who want to progress, you want to develop and work together. (L1)

\section{Management support/support in general}

This applied to support for the work locally as well as support in different parts of the socalled chain of command - with politicians at the top and teachers and pupils at the bottom. One of the questions in the interview concerned support at work, both locally at the respondents' schools as well as centrally in the municipality's education department. Most respondents felt that they received good support in their work, both locally and centrally. However, the support could be unequal, look different, and be named differently.

Local management support was in the form of a full- or part-time ad $\mu$ inistrator a management group or so-called preparatory group with team leaders from various work teams, preservice teachers, and pupil health teams. 
[...] an administrator that I have access to a couple of times a week, then I have a preparatory group, we do not call it a management group but a preparatory group that prepares questions and consists of me and four work team leaders from the preschool class, leisure, years 1-3 and 4-6. (L5)

The best support I have is my deputy principal, as we work in teams. (L2)

$[\ldots]$ need the same management support for schools with the same conditions. (L3)

Support in general from the principal or administrator was similar for the different respondents. Most considered themselves to have good support from colleagues if they had access to a team, from their immediate manager, and from the various support functions offered in the municipality, such as HR support for recruitment, personnel matters and work environment issues as well as access to legal support.

My principal and I (deputy principal) support each other; I have more experience than she has. Then we have the administration's support functions, HR department, deputy administration manager, I haven't had any great need to ask questions [..]. No worry because I am not a worried person, have routines, and have good results. (L1)

[...] there are support functions in the municipality around HR and personnel issues, a person who works on school law issues, has also had support in work environment issues, and HR. (L4)

[...] legal support is an important function when we have demanding parents [...] he supports us in our response to the Swedish Schools Inspectorate. (L5)

\section{Pedagogical leadership}

In the interviews, no direct questions were asked about pedagogical leadership, although the respondents did mention the concept and indicated that it was an important part of their daily work. The following thoughts about the concept were expressed:

Pedagogical leadership, development of the pedagogical activities, and the teaching we do - these are the absolute best. (L2)

What is stimulating? It is when you see that a weekday [...] when what you have planned is fulfilled and there is a lot to do... //... and to be a professional, to try to be the pedagogical leader, it says that you should be a pedagogical leader... it is not clearly described, what is a pedagogical leader? Is it to create conditions in some way? 


\section{Working conditions}

One of the interview questions was about which tasks the respondents experienced as stimulating and energising and which were less stimulating. The conditions to do a good job emerged as a common theme, with two subthemes being a) everyday conditions and b) conditions for skills development.

\section{a. Everyday conditions}

Several of the respondents emphasised that the 'right conditions' were essential for the work.

$[\ldots]$ it's an interesting job and there are opportunities given the right conditions. (L1)

[...] it's tough and challenging, but I have realised that I really want challenges, a rather difficult and complicated job than a monotonous and boring one... it might have to do with the fact that I have been given the conditions that make it work, but I think that it's fun. (L2)

I feel drained when I'm not given the right conditions to do a good job, because then I'm not a good leader. (L3)

$[\ldots]$ is an attractive job with the right conditions $[\ldots]$ (L3)

\section{b. Conditions for skills development}

In the interviews, the respondents were asked about their background and education. No direct question was linked to the leadership programme, although many of them mentioned this when talking about the conditions for skills development.

In the interviews, the respondents highlighted the difficulties of combining a full-time job with studies and that different municipalities in the country had different conditions for this:

There are differences in Sweden's oblong country when it comes to the state's leadership programme... this makes up 20 per cent of your work, and here it is different for different local authorities. Some stipulate $100 \%$ work plus 20 per cent study, have negotiated overtime pay... but we do not have unregulated working hours. The fact that there is also a state "puncture"... sets the conditions for local authorities to get sustainable leaders... those who decide to leave also leave the leadership programme. Big and burning... issue of education requires comparable conditions. (L3)

[...] I do the education with my left hand and feel stressed because the leadership programme “train” just keeps going and doesn’t wait for me. (L3) 
[...] difficult to do your job when you're not in place..../... the studies are an investment in us... that we will succeed, but does it have to be at that pace? ... Double-bottomed... a high study rate at the same time as being new to a leadership position and new as a principal... // ... 80/20 - you have to have time that doesn't exist. Decided that all assistant school leaders should go on the programme ... should plan for it in the education department, for exauple, have a school leader with a lot of experience who goes in ... and takes some of the pressure off during the programme, the municipality is generous - you can take your study time, you get books, everything is fine but they have missed the last part that you also need to be relieved of some of the workload that you have at the same time ... They have't done that ... They should do that.

[...] notice in the leadership programme that colleagues continue edu $\chi$ ation but have changed positions, which depends on many different things, of course... often not enough support for the assignment you've been given. (L5)

It was also emphasised that the leadership education programme contributed to the respondents' daily work:

Now doing the leadership programme, ... first year completed, now in my second. Wanted to go fast. The programme is very rewarding ... //... think it has been useful .. Meeting and discussing the things we encounter in our daily work .. has helped me a lot, we're all in the same boat and new to the job, the same problems to tackle... positive that not everyone is from the same municipality, easier to ask colleagues in RUT than your immediate colleagues. (L4)

The conditions for other kinds of education were also something that the respondents found difficult, and when asked if any other education programmes would be of further benefit for meeting the challenges of work as a school leader, the respondents highlighted budgets, work environment issues, management and more:

You learn a lot on the job... but as a school leader you have a managerial role as well... budget, finance and work environment are large parts of your everyday life... the induction to the managerial role is inadequate ... There was no induction from the education department ..to get more knowledge about the managerial role... //... leadership programme is fantastic and has given me a lot of networking as well... the managerial role needs more

[...] then there is this... You might need help with the work environment, it is important that the staff are happy at the school and the pupils... many need help with their leadership, many of the teachers who become school leaders are not used to leading staff 
groups, there is a big difference, there you need good support, it's good that the municipality requires new leaders to do the leadership programme... but it also eats into your time because the staff expect a manager to be visible. (L4)

\section{Responsibilities/tasks}

In the interviews, the respondents were given examples of tasks and areas of responsibility that were stimulating and energising and those that were not. Examples of what gave energy were when the organisation was structured and the activities were both successful and stimulating.

Positive attitude... when pupils succeed... when I see the results... cooperation, motivated staff and pupils... work in networks, that you have fun at work, and meetings with people.

I think that the work environment and staff issues are interesting... creating a team spirit and developing the work. Genuinely interested in people and activities, organisation and organisational structure... why it happens, the way it does... I think that every day is interesting and exciting. (L2)

Working as a school leader is stimulating ... extremely enjoyable, what satisfies me $\mu$ ost is when you see that things are starting to roll on their own, the staff feel safe and that they fix it. (L4)

$[\ldots]$ very stimulating at work when you look at the staff... that they are happy to develop their teaching, that they have not stopped, that they now want to find other areas of work, other opportunities, perhaps look... dare to examine themselves and their teaching because it has been a bit ... Might have been difficult before, but now we've come to the conclusion that we have such a good climate at $\mathrm{s} \chi \mathrm{hool}$ as well, and I think it's great that we have come so far. (L4)

[...] Working with structure, systematic methods, systematic quality work, frameworks, structures, goals... by strength and it is rewarding to be able to implement them as well, in different parts so... it gives a lot of energy. (L5)

Examples of things that sapped the respondents' energy were:

Social service issues... cooperation with other agencies that are supposed to give me information and tell me what to do ... The media also saps energy, difficult before... now 
just play it cool... saps energy if someone who is not my boss wants a decision from me ... administrative work. (L1)

When things go wrong, when there are disagreements among the staff, when it's difficult to meet, difficult to reach each other... personnel matters. (L2)

It's mostly parents... otherwise... if your planning is right, everything is in the diary and then changes come from above, which means that the activities you've planned have to be scrapped, those kinds of things sap my energy ... which I could use for other things instead. (L4)

[...] then I think it's about the school changing so much, quick decisions being made, the school has to rethink... cumbersome, takes time for things to settle down, you get no peace at all, we could devote ourselves to teaching and achieving good results instead of constantly having to deal with new things. (L4)

\section{Complexity of tasks}

As indicated above, there was talk of cross-pressure between the three levels of governance. Our respondents commented on this kind of pressure in the following ways:

[...] important, that there is support and trust, that you can pursue development issues, both as an educational leader and in the school... sometimes there is so much to do that there's no time for it all... and you lose interest when you are not able to work with the best parts... if there's too much of this I would get fed up. (L2)

I could work around the clock; the list of things to do is never ending. I need to prioritise myself then... decide what is most important and needs to be done and what I put on one side. (L2)

[...] a teachers' union has issued a recommendation... not to have more than 20 subordinates ...//... fight for the right conditions for a good pedagogical leader, not have so many subordinates so that you don't need to have an assistant principal, which is a construction and is not mentioned in the Education Act. (L3)

[...] cross-pressure - you're under pressure all the time, the finances have to balance and at the same time you have to ensure that all those with special needs get what they require.... make sure that the classrooms are properly equipped and that the bike racks are in good order, these are questions from... high and low... would like one of Sweden's most important jobs to be valued equally, a first class manager... puts himself last ... A little more "feel-good syndrome" ... solution-focused, forget yourself. (L3) 
[...] connected to how I am as a person, part of me is to be a manager and the other part is to be a leader ... I lean more towards becoming a manager. (L5)

\section{Discussion}

The aim of this study has been to examine how work environments, career structures, salaries, and working conditions can contribute to attracting, retaining, and motivating school leaders to stay longer in the profession. The importance of effective leadership for schools is no longer contested. Due to intensifying demands for accountability, effectiveness, efficiency, choice, and equity over time, the school leader's position has become increasingly complex. This study adds new evidence to the thin literature on leadership stability by investigating the turnover of school leaders in two municipalities in Gavleborg County and exploring how the variation in turnover can be explained by other contextual factors and school leadership characteristics, drawing on the study's findings as well as previous research on school leadership. Because our data did not permit us to fully investigate the reasons for the differences in school leadership turnover rates, the findings provide useful directions for future research into how to design effective school leadership strategies that will encourage school leaders to stay in the profession.

The study shows that the lack of certain support systems, such as time to plan and sufficient classroom resources, as well as a multitude of "bureaucratic impediments", are much more likely to drive school leaders out of the profession, e.g. lack of technology or the absence of monetary incentives. It also demonstrates the importance of collegial support and the teaching and learning circumstances that school leaders typically emphasize. The presence of a good structure and culture for collegial interaction are considered success elements for the school's internal operations (Langelotz, 2017). The study shows that the kind of relationships developed between the school leaders and the working team in the school can make a difference and may be one of the deciding factors as to whether they remain in the profession or not. It is important to provide policymakers and educators with a clearer understanding of the specific and general types of working conditions that really matter to school leaders; we hope that this study will encourage them to construct strategies that improve the working conditions in ways that will motivate school leaders to remain in post. Schools will always need new school leaders to replace those who retire, and the vibrancy and fresh thinking that they often bring with them.

This study did not look at how the school leaders operationalized pedagogical leadership. However, they all mentioned it was important to be able to lead 'learning processes' and not 
only 'doing processes'. Ståhlkrantz's (2019) research shows that the concept of pedagogical leadership is a so-called "floating signifier", a concept that is emphasised by Svedberg (2017) and that politicians use and fill with different types of meaning depending on their educational vision. Pedagogical leadership within the Swedish school system and in the training of school leaders, it is seen as a floating signifier that has perhaps had a stranglehold on school leaders when they have seen that they do not meet the requirements of the state- defined tasks. This might also help us to understand why so many school leaders choose to leave the profession after a short time.

The findings from our study demonstrate that school leaders' working conditions play a critical role in their decision to stay in or leave the profession, even more than financial compensation. The study also shows an unequal allocation of resources, both in terms of support functions and the limited time that is set aside for continuing education. Again, this could be one of the reasons why school leaders decide to leave the profession.

What school leaders really want is adequate time to plan pedagogical issues and solve problems with their colleagues, fewer classroom interruptions, and less paperwork so they have more time for their staff and pupils. They also want to place more emphasis on the curricular and managerial decisions relating to the way their schools are being run and encourage teamwork that will promote collaboration and mutual trust in the school environment. In short, what school leaders want from their work environments is a system and collegial support that enables their schools to be successful. Due to the strong correlation between teacher/school leader retention and pupil learning, we know that improvements in the teaching and learning conditions of schools will lead to a positive school experience that enables all pupils to achieve high academic standards. However, our study would not have added anything new to the body of research on school leader retention if it simply demonstrated that working conditions were positively correlated to it. Other studies have found that as well (Evers, Kneyber \& Kornhall, 2017; Skolverket, 2011; Weyler, 2020). Our findings have particular relevance in that they provide perspectives into the multifaceted structure of school leadership and its working conditions, as well as how specific workplace elements affect principals.

\section{Conclusion}

The role of the school leader has become even more important in recent years. Therefore, recruiting and retaining excellent school leaders is one of the most important drivers of a wellfunctioning education system; a system that needs to prepare pupils with complex needs to 
participate in today's knowledge-driven society. Recruiting, selecting, and retaining competent school leaders is consequently critical and crucial issue for decision-makers, to provide highquality education and a long-term view on school leadership. The internal and external factors of school leaders are interwoven and it is important for decision makers to consider both if they want to improve student achievement. It is also critical to offer school leaders with continuous professional development opportunities so that they can appropriately support the teachers in their schools. We hope that the study's key results will assist policymakers and educators in determining what is required for school leaders to remain in their positions and contribute to an effective teaching and learning environment for better student achievement.

\section{Limitations of the study}

The sample of school leaders participating in the qualitative interviews was small, which means that the results cannot be generalised to all school leaders in all municipalities. However, the study does indicate the need to explore the issues raised here in more depth and on a wider scale.

\section{Author Contributions}

Both authors contributed to all sections of the paper. Both authors have read and agreed to the published version of the manuscript.

\section{Funding}

The Faculty of Education and Business Studies, Department of Educational Sciences, University of Gavle funded this research under the internal research grants for 2020.

\section{Institutional Review Board Statement}

The study was conducted according to the guidelines of Ethics Committee and ethical principle of conducting research at the University of Gavle.

\section{Informed Consent Statement}

Informed consent was obtained from all subjects involved in the study. Research was conducted according to ethical principle of conducting the research at the Department of Educational Sciences, University of Gavle.

\section{Conflicts of Interest}

The authors declare that they have no conflicts of interest 


\section{References}

Ahrne, G. (red.) \& Svensson, P. (red.) (2015). Handbok i kvalitativa metoder. Andra upplagan. Stockholm: Liber AB.

Berg, Gunnar (2018). Skolledarskap och skolans frirum. 2a upplagan. Lund: Studentlitteratur.

Biamba, C. (2012). The Role of Principals in Government Secondary Schools in Cameroon: Demands, Constraints and Choices: A Case Study of Eight Secondary Schools. Diss. Stockholm: Stockholm University. (Studies in comparative and international education 78 Bryman, A. (2011). Samhällsvetenskapliga metoder. Andra upplagan. Stockholm: Liber AB. Darling-Hammond. L. (2010). Recruiting and Retaining Teachers: Turning Around the Race to the Bottom in High-Need Schools. Journal of Curriculum and Instruction. Vol. 4, No.1, 1632

Day, C., Sammons, P., Leithwood, K., Hopkins, D., Harris, A., Gu, Q. \& Brown, E. (2010) Ten strong claims about successful school leadership. Nottingham: NCSL.

Day, C., Gu, Q., \& Sammons, P. (2016). The impact of leadership on student outcomes: how successful school leaders use transformational and instructional strategies to make a difference. Educational Administration Quarterly, 52(2)

Drysdale, L, Gurr, D., \& Goode, H. (2016) Dare to Make a Difference: Successful Principals Who Explore the Potential of their Role. ISEA • Volume 44, Number 3, 2016

Ekholm, M., Blossing, U., Kåräng, G., Lindvall, K. \& Scherp, H-Å. (2000) Forskning om rektor. Stockholm: Liber.

Eisenberger, R., Huntington, R., Hutchison, S., \& Sowa, D. (1986). Perceived organizational support. Journal of Applied Psychology, 71, 500-507.

Elmore, Richard F. (2002) Building a New Structure for School Leadership. Washington, D.C.: The Albert Shanker Institute, 42 pages.

Erdogan, B., \& Jeanne, E. (2007). Support From the Top: Supervisors' Perceived Organizational Support as a Moderator of Leader-Member Exchange to Satisfaction and Performance Relationships. Journal of Applied Psychology, 92 (2), 321-330

Erlandsson, M. (2015). Normer och strukturer i skolutveckling: strategier hos förvaltningschefer och skolledare i implementering av inkluderande lärmiljöer. (Ifous 
rapportserie 2015:2). Från idé till praxis -vägar till inkluderande lärmiljöer i tolv svenska kommuner. http://www.ifous.se/app/uploads/2013/02/201509-Ifous-2015-2slutversion2f\%C3\%B6rwebb.pdf Hämtad: 20200912

Frelin, A. \& Fransson, G. (2019), "Principals' experiences of changes in relationships with newly qualified teachers resulting from a teacher registration reform", International Journal of Educational Management, Vol. 33

Giota, J. (2013). Individualiserad undervisning i skolan, en forskningsöversikt. (Vetenskapsrådets rapportserie 2013:3). Stockholm: Vetenskapsrådet.

Gurr, D. (2015) A Model of Successful School Leadership from the International Successful School Principalship Project, Societies, 5(1), pp. 136-150.

Håkansson, J, \& Sundberg, D. (2016) Utmärkt skolutveckling: forskning om skolförbättring och måluppfyllelse Stockholm: Natur och Kultur Ivarson Alm, E. (2014). Ledarskap i förskolan. Lund: Studentlitteratur.

Jarl, M., Blossing, U. \& Andersson, K. (2018) Att organisera för skolframgång - strategier för en likvärdig skola Stockholm: Natur \& Kultur

Langelotz, L. (2017) Kollegialt lärande i praktiken Stockholm: Natur \& Kultur Leithwood, K., \& Levin, B. (2005). Assessing School Leaders and Leadership Programme Effects on Pupil Learning. DfES Research Report 662, London DfESLeithwood, L; Patten, S \& Jantzi, D (2010). Learning Testing a Conception of How School Leadership Influences Student. Educational Administration Quarterly

Lindqvist, G. \& Nilholm, C. (2013). Making schools inclusive? Educational leaders' views on how to work with children in need of special support. International Journal of Inclusive Education, 17:1, 95-110. https://doi.org/10.1080/13603116.2011.58046[Hämtad: 20190503].

Little, J.W. (2002). Locating learning in teacher's communities of practice: Opening up problems of analysis in records of everyday work, Teaching and Teacher Education 18(8), 917946.

Ludvigsson, A. (2009). Samproducerat ledarskap: hur rektorer och lärare formar ledarskap i skolans vardagsarbete. Diss. Jönköping: Högskolan i Jönköping.

Lärarförbundet (2016) Sveriges viktigaste ledare kräver bättre villkor. https://res.cloudinary.com/lararforbundet/image/upload/v1456496433/42ffd586a342986c71e8 a466cf1cf87f/Sveriges_viktigaste_ledare_behover_battre_villkor_160121.pdf 
Nehez,J. (2015).Rektorers praktiker i möte med utvecklingsarbete. Möjligheter och hinder för planerad förändring. Doktorsavhandling. Göteborgs universitet. Utbildningsvetenskapliga fakulteten. ISBN 978-91-7346-849-7.

Nilsson, M. (2020) Chefernas omsättning - förödande för skolan

https://www.skolledarna.se/Skolledaren/Ledaren/2020/chefernas-omsattning/

Norqvist, L. \& Poromaa Isling, P. (2020). Skolledarskap i Sverige: en forskningsöversikt 2014-2018. Nordic Studies in Education, 40(2), 167-

187. https://doi.org/10.23865/nse.v40.2230

OECD (2020), TALIS 2018 Results (Volume II): Teachers and School Leaders as Valued Professionals, TALIS. OECD Publishing: Paris

OECD (2014) Trends shaping education. OECD Publishing: Paris

Pollock, K., Wang, F., \& Hauseman, D. (2015). Complexity and volume: An inquiry into factors that drive principals' work. Societies, 5, 537-565.

Rhoades, L., \& Eisenberger, R. (2002). Perceived Organizational Support: A Review of the Literature. Journal of Applied Psychology, 87(4), 698-714

Skolinspektionen (2010:15) Kvalitetsgranskning - Rektors ledarskap. Stockholm:

Skolinspektionen.

Skolinspektionen (2012:1) Kvalitetsgranskning - Rektors ledarskap. Stockholm:

Skolinspektionen.

Skolinspektionen (2014). Från huvudmannen till klassrummet -tät styrkedja viktig för förbättrade kunskapsresultat. Stockholm: Skolinspektionen.

Skolinspektionen (2019b). Årsrapport 2018 - Skillnader i skolkvalitet och strategisk styrning. Stockholm: Skolinspektionen.

Skolinspektionen (2019). Tematisk kvalitetsgranskning: Huvudmannens arbete för kontinuitet på skolor med många rektorsbyten - Utan spaning ingen aning. Stockholm: Skolinspektionen.

Skollagen (SFS 2010:800)

Skolverket (2012) Allmänna råd Systematiskt kvalitetsarbete - för skolväsendet Skolverket (2019b). TALIS 2018 En studie om lärares och rektorers arbete i grund- och gymnasieskolan, del-rapport 1. Rapport 481. Skolverket. Stockholm: Fritzes. 5 Skolverket (2015b). Svenska rektorers erfarenhet i nordiskt perspektiv: En analys av TALIS 2013, Stockholm: Fritzes.

Skolverket (2005, 2007, 2011d, 2017) Lägesbedömningar. Rapporter. Stockholm: Fritzes. 
Skolverket (2019a). Pedagogisk personal i skola och vuxenutbildning läsåret 2018/19.

Stockholm: Fritzes.

SOU 1964:53 Organisation av skolledningen i grundskolan

SOU 1974:53 Skolans arbetsmiljö

SOU 1988:20 En förändrad ansvarsfördelning och styrning på skolområdet

SOU 1997:121 Skolfrågor - Om skola i en ny tid

SOU 2004:116 Skolans ledningsstruktur - Om styrning och ledning i skolan

Spillane, J. P. (2015). Leadership and learning: Conceptualizing relations between school administrative practice and instructional practice. Societies, 5,: 277-294.

Ståhlkrantz, K. (2019). Rektorers pedagogiska ledarskap - en kritisk policyanalys.

Diss.https://www.diva-portal.org/smash/get/diva2:1272783/FULLTEXT01.pdf[Hämtad: 20200614]

Tivenius, O. (2015). Uppsatsens inre liv. Lund: Studentlitteratur

Tschannen-Moran, M.; Gareis, C.R. (2015) Faculty trust in the principal: An essential ingredient in high-performing schools. Journal of Educational Administration, 53, 66-92

Vetenskapsrådet (2017). God forskningssed. Stockholm.

Weyler, K. (2020) Stor omsättning av rektorer. Artikel i Skolledaren Nr 5/20

https://www.skolledarna.se/Skolledaren/Artikelarkiv/2020/stor-omsattning-av-rektorer/ 